\title{
Hubungan customer engagement melalui Instagram @perpustakaandikbud dengan minat kunjungan perpustakaan di kalangan follower aktif
}

\author{
Rachmi Anindyaputri ${ }^{1}$, Agus Rusmana ${ }^{2}$, Neneng Komariah ${ }^{3}$ \\ ${ }^{1}$ Perpustakaan Pusat Universitas Muhammadiyah Jakarta \\ Jl. KH. Ahmad Dahlan, Cireundeu, Ciputat Timur, Jakarta Selatan, 15419 \\ 2,3Program Studi Perpustakaan dan Sains Informasi, Universitas Padjadjaran \\ Jl. Raya Bandung-Sumedang Km. 21, Jatinangor, Sumedang, Jawa Barat, 45363 \\ E-mail: 1rachmi.anindyaputri@staff.umj.ac.id, 2agus.rusmana@unpad.ac.id, \\ ${ }^{3}$ neneng.komariah@unpad.ac.id
}

Received: January 2020; Accepted: October 2020; Published: December 2020

\begin{abstract}
The internet in the business world have led to new promotion forms using social media known as customer engagement, a series of activities carried out by social media users to engage with brands or organizations. The Ministry of Education and Culture's Library via Instagram @perpustakaandikbud as institutions that provide information services used social media in their promotional activities. This study aimed to determine the customer engagement's correlation through Instagram @perpustakaandikbud with interest in visiting the library among active followers. This study used quantitative methods with a correlational approach with the research sample was 83 respondents, obtained by using a simple random sampling technique. The researchers were collected research data using questionnaires, interviews, and literature studies. The inferential correlation test used a simple linear regression analysis using the product-moment formula. Results showed that customer engagement, based on the indicators of absorption, dedication, vigor, and interaction, had a significant relationship with interest in visiting the library. This was proven by testing the major hypothesis; namely, the calculation results obtained a correlation coefficient of 0.521. It obtained a ${ }^{t}$ count of 4,417 and ttable of 1,663. The ${ }^{t}$ count was more significant than the table, so the hypothesis was accepted. Customer engagement through Instagram @ perpustakaandikbud correlated with the followers' interest in visiting the Ministry of Education and Culture's Library. This research concludes that Instagram social media is an effective library promotion media in increasing user's interest.
\end{abstract}

Keywords: Customer engagement; Instagram social media; Interest in visiting the library

\begin{abstract}
Abstrak
Internet dalam dunia bisnis memunculkan sebuah bentuk promosi baru memanfaatkan media sosial, misalnya keterlibatan konsumen (customer engagement) sebagai serangkaian aktivitas yang dilakukan pengguna media sosial untuk terlibat dengan merek atau organisasi. Perpustakaan Kementerian Pendidikan dan Kebudayaan melalui Instagram @perpustakaandikbud sebagai lembaga penyedia pelayanan informasi yang memanfaatkan media sosial dalam kegiatan promosi. Penelitian ini bertujuan untuk mengetahui hubungan customer engagement melalui Instagram @perpustakaandikbud dengan minat kunjungan perpustakaan di kalangan follower aktif. Penelitian ini menggunakan metode penelitian kuantitatif melalui pendekatan korelasional dengan sampel penelitian berjumlah 83 responden dan diambil menggunakan teknik sampling acak sederhana. Peneliti mengumpulkan data penelitian menggunakan angket, wawancara, dan studi literatur. Adapun uji korelasi inferensial menggunakan uji analisis regresi linear sederhana dan menggunakan rumus product moment. Hasil penelitian menunjukkan bahwa customer engagement yang dilihat dari indikator absorption, dedication, vigor, dan interaction memiliki hubungan yang signifikan dengan minat kunjungan perpustakaan. Hal ini dibuktikan melalui pengujian hipotesis mayor, yaitu hasil penghitungan didapatkan koefisien korelasi sebesar 0,521. Selanjutnya didapatkan thitung 4,417 dan tabel 1,663. Dengan demikian thitung lebih besar dari tabel sehingga hipotesis diterima. Jadi customer engagement melalui Instagram @perpustakaandikbud telah memiliki hubungan dengan minat kunjungan follower ke Perpustakaan Kemendikbud. Simpulan penelitian ini ialah media sosial Instagram merupakan media promosi perpustakaan yang efektif dalam meningkatkan minat kunjungan pengguna.
\end{abstract}

Kata Kunci: Keterlibatan konsumen; Media sosial Instagram; Minat kunjungan perpustakaan 


\section{PENDAHULUAN}

Promosi perpustakaan merupakan kegiatan komunikasi yang dilakukan pada pengguna aktual dan potensial. Promosi perpustakaan bertujuan memperkenalkan semua manfaat perpustakaan kepada pengguna dan pengguna dapat mengetahui fungsi perpustakaan. Kegiatan promosi berguna menginformasikan pelayanan yang diberikan perpustakaan sehingga pengguna tertarik untuk mengunjungi dan memanfaatkan koleksi serta pelayanan perpustakaan.

Kegiatan promosi di perpustakaan di antaranya iklan, publikasi, dan hubungan masyarakat. Promosi perpustakaan dapat melakukan strategi agar target perpustakaan dapat tercapai. Adapun promosi dapat dilakukan melalui berbagai media, baik media cetak seperti pamflet, brosur, poster, maupun media elektronik seperti iklan televisi dan radio. Pada era digital seperti sekarang, media sosial merupakan pilihan yang digunakan sebagai sarana promosi.

Media sosial sebagai salah satu bentuk dari perkembangan teknologi komunikasi di era digital. Media sosial didefinisikan sebagai suatu grup aplikasi berbasis internet yang menggunakan ideologi dan teknologi Website 2.0, yang memungkinkan pengguna untuk membuat atau bertukar informasi (Kaplan \& Haenlein, 2017). Website 2.0 adalah kondisi di mana batas antara media dan khalayak sudah tidak jelas lagi. Pada era Website 2.0, khalayak mengendalikan media. Di mana khalayak dapat dengan bebas memilih dan berpartisipasi dengan cara mengubah, menciptakan ulang, dan menyebarkan informasi.

Penggunaan internet dan media sosial sudah sangat populer di kalangan masyarakat Indonesia. Internet dan media sosial mulai digunakan dalam bidang pendidikan.

"Seiring berjalannya waktu, perkembangan fungsi dan tujuan internet tidak hanya diperuntukkan untuk keperluan edukasi dan komersial saja, melainkan dikembangkan lebih lanjut untuk fungsi komunikasi yang disebut dengan media sosial" (Sherlyanita \& Rakhmawati, 2016).

Media sosial merupakan media komunikasi dua arah yang dapat dijadikan media promosi bagi organisasi untuk membagikan konten publikasi produk dan jasa. Selain itu, media sosial pun dapat digunakan untuk melakukan interaksi dan melihat secara langsung respons konsumen (costumer) dari komentar yang disampaikan melalui kolom komentar. Masyarakat menggunakan media sosial cukup tinggi sehingga beberapa lembaga tertarik menggunakan media sosial sebagai sarana promosi.

Media sosial sendiri untuk kegiatan promosi memiliki potensi sebagi wadah bagi institusi/lembaga untuk mengiklankan produk/jasa. Selain itu, media sosial sebagai alat untuk mengembangkan produk/jasa yang melibatkan konsumen, observasi, dan melakukan analisis konten berbasis pengguna (user-generated content). Institusi/lembaga melalui promosi di media sosial perlu menggeser tujuan promosi dari sekadar ingin menjual dengan membuat hubungan baik pada konsumen.

Media sosial sebagai media promosi mengalami peningkatan penggunaan khususnya pada platform berbasis mediasharing yang memberikan pengaruh pada pengguna untuk melakukan aktivitas online terkait suatu merek (online brand- 
related activities), yaitu aktivitas yang dilakukan pengguna media sosial untuk terlibat ('engage') dengan merek. Aktivitas yang dilakukan beragam dan menimbulkan tingkatan keterlibatan yang berbeda-beda.

Ketika pengguna melihat konten publikasi seperti iklan maka pengguna sedang mengonsumsi media terkait suatu merek (brand-related media). Ketika seorang konsumen memberikan tanda suka (like) atau komentar pada sebuah konten publikasi merek tertentu, maka pengguna berpindah dari tingkat konsumen ke tingkat kontributor (contributor). Tingkatan tertinggi adalah ketika pengguna mengunggah pesan atau informasi yang membahas merek tertentu. Di mana pada titik ini pengguna membuat pesan terkait merek. Maka keterlibatan pengguna dengan merek ini disebut customer engagement.

Secara konsep, Brodie, Ilic, Juric, and Hollebeek (2013) mengatakan bahwa customer engagement dapat dilihat sebagai bidang hubungan pemasaran yang diperluas. Sesuai perspektif servicedominant (S-D), customer engagement sebagai suatu pandangan yang melampaui pemasaran. Hal ini sangat berlawanan dengan pandangan hubungan pemasaran tradisional yang masih mengacu pada produk atau disebut goods-dominant (G-D). Perluasan perspektif ini sebagai sebuah bukti bahwa perilaku konsumen dalam pengalaman interaktif telah banyak didukung lingkungan (co-creative) yang kompleks, di mana pengalaman ini diartikan sebagai kegiatan engaging.

Secara istilah, engagement diartikan sebagai keterlibatan atau partisipasi. Beberapa ahli menginterpretasikan customer engagement sebagai interaksi antara konsumen dengan perusahaan.
Vivek, Beatty, and Morgan (2012) mendefinisikan customer engagement sebagai intensitas partisipasi individu dan hubungannya dengan penawaran dan aktivitas organisasi yang muncul dari pelanggan dan organisasi.

Secara sederhana, customer engagement merupakan usaha yang melibatkan pelanggan melalui interaksi secara fisik dan emosional antara organisasi dan pengguna. Customer engagement pun dapat dikatakan sebagai sebuah alat untuk membangun hubungan jangka panjang dengan pengguna. Maka pengguna melalui media sosial dapat mewujudkan customer engagement dengan memperhatikan hubungan antara organisasi dengan pelanggan. Selain itu, customer engagement pun dapat meningkatkan kemampuan organisasi dalam melakukan komunikasi secara interaktif dengan pelanggan. Pelanggan tidak lagi dilihat sebagai penerima pasif dari suatu kegiatan pemasaran, tetapi pelanggan sebagai partisipan aktif dalam sebuah proses interaktif (co-creation) yang bernilai. Oleh karena itu, sifat dasar media sosial adalah interaktif dan co-creative. Customer engagement sendiri memiliki bentuk sederhana yang menggunakan pengukuran, seperti rating, jumlah like, komentar, dan share.

Customer engagement dan hubungan interaktif dengan objek membutuhkan adanya pengalaman yang dirasakan pengguna dan nilai instrumental dari interaksi tertentu dengan brand. Hubungan interaktif pelanggan ini dapat menimbulkan beberapa konsekuensi, di antaranya adalah hal-hal yang melibatkan konsep kepercayaan, kepuasan, komitmen, koneksi emosional, penguatan, dan loyalitas. Di antara semua konsekuensi ini, loyalitas, komitmen, dan penguatan 
merupakan konsep paling menonjol dalam konteks komunitas brand online.

Berdasarkan hal ini, Brodie, Hollebeek, Juric', and Ilic' (2011) mengemukakan bahwa customer engagement mencerminkan keadaan psikologis berdasarkan pengalaman interaktif konsumen dengan agen/objek tertentu dalam suatu hubungan layanan yang tunduk pada konteks dimensi kognitif, emosional, dan behavioral. Berdasarkan gagasan ini, dapat dipahami bahwa customer engagement menggambarkan serangkaian aktivitas yang melibatkan konsumen dengan objek tertentu, seperti brand atau organisasi secara langsung atau secara tidak langsung melalui media yang mengomunikasikan nilai brand atau organisasi tersebut. Semua aktivitas ini dapat memberikan pengalaman interaktif bagi pelanggan dan memberikan pengaruh psikologis konsumen yang berhubungan dengan dimensi kognitif, emosional, dan behavioral.

Menurut Hollebeek, Glynn, and Brodie (2014), customer engagement dapat dilihat dari 4 dimensi yang berbeda yaitu: a) absorption, menggambarkan ketika konsumen tertarik dan memperhatikan produk/jasa dan layanan tertentu; b) dedication, mengarah pada rasa kepemilikan di mana konsumen merasa senang dan bangga pada institusi/lembaga yang menyebabkan konsumen seringkali terinspirasi; c) vigor, mengacu pada level energi dan kegembiraan konsumen yang memiliki keinginan untuk memberikan usaha dan waktu yang lebih bagi institusi/lembaga sehingga konsumen cenderung memiliki loyalitas pada institusi/lembaga; d) interaction, mengarah pada berbagai interaksi dan hubungan timbal-balik dengan interaksi antara konsumen dengan staf pelayanan, dengan institusi/lembaga, maupun antar konsumen itu sendiri.

Pada dasarnya, customer engagement memiliki tujuan utama membuat pengunjung menjadi konsumen dan membuatnya loyal pada brand. Customer engagement dalam organisasi dapat menjangkau pengunjung lokasinya sulit dijangkau. Selain itu, melalui media sosial, konten dapat disebarkan kepada lebih beragam konsumen dibandingkan menggunakan media massa sehingga media sosial menciptakan sebuah jaringan di mana konten dapat mudah didistribusikan kepada orang banyak.

Instagram adalah salah satu media sosial yang paling banyak digunakan sebagai media promosi karena sifatnya yang tidak berbasis percakapan, melainkan berbagi media (media-sharing). Hal ini memungkinkan pengguna dapat membuat dan membagikan foto, video, dan infographic. Hirschmann (2018) menuturkan bahwa 49\% masyarakat Indonesia menggunakan Instagram dan Twitter sebagai plaform marketing. Statista Research Department (2018) juga menunjukkan hal serupa bahwa responden khususnya perempuan di Indonesia berjumlah $67.5 \%$ mendapatkan informasi untuk belanja menggunakan sosial media, contohnya Instagram. Berdasarkan kedua rujukan ini, Instagram telah berevolusi sebagai perangkat lunak (platform) yang dapat berbagi foto, video, dan gambar bergerak Graphics Interchange Format (GIF). Kini Instagram telah bersaing dengan Snapchat dengan fitur live video yaitu Instagram Stories dan Instagram Live.

Gibbs, Meese, Arnold, Nansen, and Carter (2014) menyatakan bahwa Instagram digunakan sebagai penyimpan hasil dokumentasi dari pengalaman individu. 
Foto digunakan untuk merekam berbagi elemen materi penting, ritual, dan pertemuan bersama teman dan keluarga. Berbagi foto bertujuan untuk menandakan dan mengomunikasikan kehadiran sebuah peristiwa penting dan pengalaman ke jejaring sosial yang lebih luas. Pengalaman individu dapat menciptakan rasa kedekatan, koneksi, dan kehadiran bersama dengan teman, keluarga, dan kenalan yang mungkin tidak hadir.

Dengan demikian, banyak institusi/lembaga menggunakan Instagram sebagai media promosi. Arceneaux and Dinu (2018) pun menjelaskan bahwa Instagram sebagai media promosi telah meningkatkan kemampuan komunikasi digital bagi pelanggannya. Media sosial ini memberikan pelanggan memiliki sudut pandang pribadi terhadap institusi/lembaga dan memunculkan rasa kebersamaan antara para followers. institusi/lembaga dapat memublikasikan foto, video produk, dan menyoroti pengalaman pelanggan dengan produk mereka.

Customer engagements merupakan sebuah proses dalam aspek fisik, emosional, dan kognitif yang berusaha melibatkan dan berinteraksi dengan pelanggan. Selain itu, customer engagements pun siap menyediakan feedback sebagai bentuk kepedulian terhadap konsumen. Maka, promosi melalui customer engagement harus mampu menumbuhkan minat konsumen agar konsumen mau menggunakan produk/jasa yang disediakan institusi/lembaga.

Minat adalah keinginan individu terhadap sesuatu. Minat individu dapat dipengaruhi beberapa faktor, di antaranya kondisi fisik, kondisi psikis, dan lingkungan sosial. Minat individu pada suatu hal akan tinggi apabila individu tersebut memiliki kondisi fisik yang baik. Individu dengan fisik yang sehat akan dapat melakukan kegiatan dengan baik pula. Minat individu pun dapat berubah seiring perubahan kondisi psikis. Lingkungan sosial dapat memengaruhi minat individu karena individu memiliki kecenderungan untuk melakukan hal yang bisa diterima oleh lingkungan sosialnya.

Media telah memberikan berbagai informasi dan pengetahuan baru mengenai suatu hal bagi individu. Informasi dalam media biasanya cenderung memengaruhi pengguna dan memberikan argumen yang kuat. Maka informasi dari media dapat menumbuhkan minat individu. Customer engagement melalui media sosial bertugas sebagai media yang digunakan institusi/lembaga untuk memengaruhi sikap konsumen agar konsumen memiliki keinginan untuk menggunakan produk atau pelayanan yang disediakan.

Customer engagement pada akhirnya membentuk komunitas online yang berorientasi pada brand. Konsumen melalui media sosial dapat langsung berinteraksi dengan institusi/lembaga dalam memberikan feedback dan menerima respons dari institusi/lembaga. Hal ini membuat konsumen dapat langsung memberikan penilaian kepada institusi/lembaga. Selain itu, konsumen pun dapat saling berinteraksi dan berbagi pengalaman dengan konsumen lainnya. Konsumen dapat saling bertukar informasi dan menentukan komunikasi yang dilakukan dengan institusi/lembaga melalui interaksi tersebut. Institusi/lembaga dapat memanfaatkan situasi ini untuk memengaruhi sikap konsumen agar sejalan dengan tujuan institusi/lembaga melalui strategi yang tepat. 
Penelitian yang berkaitan dengan customer engagement banyak dilakukan terhadap promosi produk dari institusi/lembaga yang berorientasi profit, contohnya penelitian tentang pengaruh customer engagement melalui media sosial terhadap kepercayaan merek, yakni studi kasus Instagram Shopee dari penelitian Mahayani, Aknuranda and Kusyanti (2019). Hasil penelitian ini menunjukkan bahwa dari 4 variabel customer engagement, 3 di antaranya berpengaruh terhadap kepercayaan merek secara signifikan. Selanjutnya penelitian yang dilakukan Rahmawati and Sanaji (2015) mengenai pengaruh customer engagement terhadap kepuasan pelanggan dan kepercayaan merek serta dampaknya pada loyalitas terhadap merek. Hasil penelitian menunjukkan bahwa customer engagement berpengaruh positif terhadap kepuasan pelanggan dan kepercayaan merek, tetapi tidak berpengaruh terhadap loyalitas merek. Adapun penelitian yang dilakukan oleh Sukamdewi and Prihatsanti (2017) mengenai hubungan antara brand trust dengan customer engagement pada pengguna Wardah kosmetik, menjelaskan bahwa terdapat hubungan positif yang signifikan antara brand trust dengan customer engagement.

Penelitian tentang kegiatan promosi sebuah perpustakaan menggunakan media sosial cukup menarik terutama dapat dilihat dari aspek customer engagement dan berkaitan dengan minat kunjungan ke perpustakaan. Perpustakaan merupakan institusi/lembaga yang tidak berorientasi profit dan masih sedikit perpustakaan yang menggunakan media sosial sebagai media promosi. Promosi dalam pengelolaan suatu perpustakaan tidak kalah penting dibandingkan kegiatan lainnya karena melalui promosi masyarakat dapat mengenal perpustakaan. Selain itu, masyarakat pun dapat mengetahui sarana, fasilitas, pelayanan, koleksi, dan pelbagai kegiatan pembelajaran di perpustakaan.

Perpustakaan melalui kegiatan promosi dapat menumbuhkan minat masyarakat untuk mengunjungi perpustakaan. Minat kunjungan perpustakaan dapat diartikan sebagai keinginan individu untuk mengunjungi perpustakaan dan memanfaatkan pelayanan dan koleksi perpustakaan. Minat terdiri dari aspek kognitif dan aspek afektif (Syafi'i, Marfiyanto, \& Rodiyah, 2018). Aspek kognitif didasari atas apa yang diketahui dan pernah dipelajari sedangkan aspek afektif didasari atas perasaan dan emosi terhadap objek. Minat pengguna untuk berkunjung ke perpustakaan dapat memiliki satu aspek tambahan, yaitu aspek konatif yang ditunjukkan melalui tindakan berkunjung ke perpustakaan.

Di era teknologi informasi sekarang ini, perpustakaan pun melakukan kegiatan promosi menggunakan media sosial. Salah satu perpustakaan yang menggunakan media sosial sebagai media promosi adalah Perpustakaan Kementerian Pendidikan dan Kebudayaan (Kemendikbud). Perpustakaan ini adalah perpustakaan khusus yang berada di bawah naungan Kemendikbud yang memiliki media sosial berupa Instagram bernama @perpustakaandikbud. Alamat Instagram ini memiliki lebih dari 11 ribu followers yang berasal dari berbagai macam latar belakang, mulai dari pegawai Kemendikbud, siswa, guru, mahasiswa, dosen, pustakawan, pengamat pendidikan, pengamat perpustakaan, dan pengguna yang tertarik dengan Perpustakaan Kemendikbud. 
Instagram @perpustakaandikbud memiliki konten publikasi yang terdiri dari dua kategori, yaitu konten utama dan konten selingan. Konten utama merupakan konten yang paling diutamakan untuk dipublikasikan karena berisikan informasi mengenai Perpustakaan Kemendikbud, seperti fasilitas, pelayanan, koleksi, repositori, library rules, dan user-education. Semua konten ini bertujuan untuk mengedukasi followers mengenai Perpustakaan Kemendikbud. Selain itu, konten selingan meliputi informasi di luar konten utama yang bisa menarik minat masyarakat, seperti tips \& trik, dan giveaway. Daya tarik konten publikasi Instagram @perpustakaandikbud terletak pada bagian visual dan isi pesan. Perpustakaan biasanya setiap menulis pesan (posting) menggunakan infographic agar ilustrasi menarik, kalimat yang mudah dipahami, dan disertai kata atau kalimat gambaran ilustrasi (caption) yang sesuai.

Dengan demikian, institusi/lembaga dalam melakukan persuasi customer engagement Instagram @perpustakaandikbud akan menyampaikan pesan (posting) konten publikasi untuk menarik konsumen. Selanjutnya, konsumen dapat berinteraksi dengan perpustakaan Kemendikbud dan konsumen lain untuk saling bertukar informasi. Customer engagement dapat dilihat dari serangkaian aktivitas engagement, di antaranya absorption, dedication, vigor, dan interaction. Aktivitas tersebut akan mampu membuat konsumen memproses informasi dengan harapan adanya perubahan sikap pada konsumen terhadap Perpustakaan Kemendikbud, yaitu berupa minat untuk mengunjungi Perpustakaan Kemendikbud.

Sesuai uraian tersebut, rumusan masalah dalam penelitian ini mengenai hubungan antara customer engagement Instagram @perpustakaandikbud dengan minat kunjungan followers ke Perpustakaan Kemendikbud. Adapun tujuan penelitian ini untuk mengetahui hubungan antara dimensi absorption Instagram @perpustakaandikbud dengan minat kunjungan perpustakaan, untuk mengetahui hubungan antara dimensi dedication Instagram @perpustakaandikbud dengan minat kunjungan perpustakaan, untuk mengetahui hubungan antara dimensi vigor Instagram @perpustakaandikbud dengan minat kunjungan perpustakaan, dan untuk mengetahui hubungan antara dimensi interaction Instagram @perpustakaandikbud dengan minat kunjungan perpustakaan.

\section{METODE PENELITIAN}

Metode penelitian yang digunakan dalam penelitian ini adalah metode penelitian kuantitatif melalui pendekatan korelasional. Penelitian korelasional bertujuan untuk mengetahui ada tidaknya hubungan antara dua variabel atau lebih dan bagaimana hubungan antara variabel tersebut (Safira \& Irawati, 2020). Penelitian ini dilaksanakan di Perpustakaan Kemendikbud selama bulan Juni-Juli 2018. Objek penelitian adalah followers akun Instagram @perpustakaandikbud yang sesuai kriteria penelitian. Perpustakaan Kemendikbud telah menggunakan media sosial Instagram sejak 2017 namun baru dimulai awal 2018 digunakan sebagai media promosi sehingga hal ini menarik untuk diteliti mengenai efektivitasnya.

Populasi penelitian adalah followers akun Instagram @perpustakaandikbud yang aktif memberikan tanda suka (like) atau komentar pada content yang ditulis berjumlah 485 followers. Sampel yang 
diambil menggunakan teknik simple random sampling dan dihitung menggunakan rumus Slovin, sejumlah 83 orang. Data penelitian dikumpulkan menggunakan angket yang disebarkan kepada sampel penelitian yang sudah ditentukan. Adapun pengolahan data dilakukan menggunakan metode analisis statistik deskriptif dan statistik inferensial. Data yang dianalisis pada analisis deskriptif adalah data responden dan data penelitian. Data responden terdiri dari usia, pendidikan, pekerjaan, frekuensi kunjungan ke Perpustakaan Kemendikbud, dan durasi setiap kunjungan. Sementara itu, data penelitian terdiri dari customer engagement dan minat kunjungan perpustakaan. Data penelitian untuk customer engagement dilihat dari dimensi absorption, dedication, vigor, dan interaction. Pengujian hipotesis pada analisis inferensial dilakukan menggunakan korelasi rank spearman.

\section{HASIL DAN PEMBAHASAN}

Peneliti mendapatkan data dari pengolahan data primer yang bersumber dari penyebaran angket kepada responden penelitian, yaitu follower Instagram @ perpustakaandikbud sebanyak 83 orang. Data yang didapatkan terdiri dari data responden dan data penelitian yang kemudian dikelompokkan dan dimasukkan ke dalam tabel distribusi frekuensi. Peneliti kemudian melakukan analisis data responden untuk melihat karakteristik responden. Setelah itu peneliti melakukan analisis jawaban responden terhadap pernyataan seputar data penelitian. Peneliti lalu mengategorikan jawaban responden ke dalam klasifikasi tinggi, sedang dan rendah. Peneliti akhirnya melakukan tabulasi silang dan analisis statistik inferensial.

Berdasarkan hasil analisis responden, diketahui bahwa berdasarkan pengelompokan usia, dari 83 responden, sebanyak 37 responden $(44,6 \%)$ berusia 21 29 tahun dan sebanyak 19 responden $(22,9 \%)$ berusia antara 12-20 tahun. Responden sejumlah 14 orang (16,9\%) berusia $>47$ tahun, 9 orang $(10,8 \%)$ berusia 30-38 tahun, 3 orang $(3,6 \%)$ berusia $39-47$ tahun dan 1 orang $(1,2 \%)$ berusia $<12$ tahun. Hal ini menunjukkan bahwa sebagian besar responden berada pada usia remaja. Hal ini sesuai survei yang dilakukan Riyanto (2019) yang menyatakan bahwa sebagian besar pengguna Instagram ada pada rentang usia 18 hingga 34 tahun.

Sementara itu, berdasarkan pengelompokan pendidikan terakhir atau yang sedang ditempuh, 43 responden $(51,8 \%)$ berpendidikan Sarjana (S-1) dan 20 responden $(24,1 \%)$ berpendidikan Sekolah Menengah Atas (SMA). Selanjutnya 9 responden (10,8\%) berpendidikan Magister (S-2), 8 responden (9,7\%) berpendidikan Diploma, 1 responden (1,2\%) berpendidikan Doktor (S-3) dan 2 responden $(2,4 \%)$ berpendidikan Sekolah Menengah Pertama (SMP). Responden berdasarkan pengelompokan pekerjaan, dari 83 responden, sebanyak 45 orang $(54,2 \%)$ adalah pelajar atau mahasiswa, 15 orang $(18,2 \%)$ adalah karyawan swasta, 10 orang $(12 \%)$ pegawai negeri, 7 orang $(8,4 \%)$ wirausaha dan 6 orang $(7,2 \%)$ menjawab lainnya. Ini menunjukkan bahwa sebagian besar responden adalah pelajar atau mahasiswa.

Peneliti pun melakukan analisis frekuensi kunjungan responden ke Perpustakaan Kemendikbud dalam kurun waktu satu minggu. Responden sebanyak 
73 orang (88\%) mengunjungi perpustakaan sebanyak 1-3 kali dalam seminggu. Responden berjumlah 7 orang $(8,4 \%)$ berkunjung sebanyak 3-4 kali dalam seminggu dan 3 orang $(3,6 \%)$ sebanyak 5-7 kali. Sesuai data ini, terlihat bahwa hampir seluruh responden mengunjungi Perpustakaan Kemendikbud sebanyak 1 hingga 3 kali dalam seminggu. Frekuensi kunjungan ini dapat dikatakan cukup wajar, mengingat sebagian besar responden adalah pelajar dan mahasiswa yang memiliki waktu terbatas untuk mengunjungi perpustakaan. Sebagian besar responden hanya dapat mengunjungi Perpustakaan Kemendikbud pada hari Sabtu. Mereka menghabiskan waktu sekitar 1-4 jam pada setiap kunjungan. Durasi ini dapat dikatakan cukup lama, mengingat kunjungan responden terbanyak pada hari Sabtu meski pada hari tersebut jam layanan hanya dibuka sampai Pukul 14.00.

Sebagian besar pengguna Perpustakaan kemendikbud adalah pelajar atau mahasiswa sebagai pengguna utama Instagram. Setelah menganalisis data responden, peneliti melakukan analisis data penelitian yang terdiri dari 2 variabel, yaitu customer engagement dan minat kunjungan. Customer engagement terdiri dari 4 dimensi yaitu dimensi absorption, dedication, vigor dan interaction. Keempat dimensi ini dilihat dari konten publikasi Instagram @perpustakaandikbud. Konten publikasi dalam kegiatan promosi Perpustakaan Kemendikbud dibagi menjadi dua kategori, yaitu konten utama dan konten selingan. Konten utama merupakan konten yang paling diutamakan untuk dipublikasikan karena berisi informasi mengenai perpustakaan yang bersangkutan, seperti fasilitas, pelayanan, koleksi, repositori, library rules, dan user-education. Semua konten ini bertujuan untuk melakukan edukasi followers mengenai Perpustakaan Kemendikbud. Selain itu, konten selingan meliputi informasi di luar konten utama yang bisa menarik minat masyarakat, seperti tips \& trik, dan giveaway.

Customer engagement dalam dimensi absorption dapat diartikan sebagai penyerapan. Absorption dapat dipahami sebagai istilah yang menggambarkan ketika konsumen merasa tertarik dan mulai memperhatikan objek, berupa produk, jasa, atau layanan tertentu. Absorption dalam penelitian ini terdiri dari tiga indikator yang menggambarkan situasi ketika konsumen melihat konten publikasi di Instagram @perpustakaandikbud yang berfungsi sebagai salah satu media promosi. Konten publikasi ini akan memunculkan rasa tertarik dan ingin tahu follower sehingga follower akan lebih memperhatikan konten publikasi dengan lebih seksama, contohnya follower saat membaca caption yang menyertai konten publikasi tersebut.

Berdasarkan indikator ketertarikan follower pada pesan (posting) @ perpustakaandikbud, hampir seluruh responden menyatakan bahwa mereka merasa tertarik pada konten publikasi yang ditulis (posting) pada Instagram @perpustakaandikbud. Pada indikator perhatian, hampir seluruh follower pada pesan (posting) @perpustakaandikbud memperhatikan konten publikasi. Hal ini didukung indikator follower membaca caption post @perpustakaandikbud yang menunjukkan hampir seluruh responden menyatakan bahwa mereka membaca caption dari konten publikasi yang ditulis (post)Instagram @perpustakaandikbud.

Customer engagement dalam dimensi dedication mengarahkan konsumen pada 
rasa memiliki, yaitu konsumen merasa senang dan bangga pada institusi/lembaga yang menyebabkan konsumen seringkali terinspirasi. Dimensi dedication dalam penelitian ini memiliki tiga indikator yang menggambarkan situasi ketika follower menyukai pesan publikasi yang ditulis (posting) di Instagram@perpustakaandikbud hingga ke titik saat follower merasa terinspirasi. Follower merasa bangga ketika melihat atau membaca konten publikasi tersebut.

Berdasarkan indikator follower yang menyukai pesan (posting) @perpustakaandikbud, hampir seluruh responden menyukai pesan publikasi yang ditulis (posting) Instagram @perpustakaandikbud. Pada indikator follower yang terinspirasi hasil pesan (posting) @perpustakaandikbud, hampir seluruh responden merasa terinspirasi ketika memperhatikan pesan publikasi yang ditulis (posting) Instagram @perpustakaandikbud. Sementara itu, pada indikator follower yang bangga pada pesan yang ditulis (posting) @perpustakaandikbud, sebagian besar responden menyatakan bahwa mereka merasa bangga ketika melihat atau membaca pesan publikasi yang ditulis (posting)Instagram @perpustakaandikbud.

Customer engagement dalam dimensi vigor menekankan level energi dan kegembiraan konsumen di mana konsumen berkeinginan memberikan usaha dan waktu yang lebih bagi institusi/lembaga. Konsumen dalam hal ini cenderung memiliki loyalitas pada institusi/lembaga. Pada penelitian ini, dimensi vigor terdiri dari dua indikator yang menggambarkan situasi ketika follower merasa senang setiap kali melihat dan memperhatikan konten publikasi yang dipromosikan melalui Instagram @ perpustakaandikbud. Follower cenderung loyal dan menantikan setiap pesan publikasi baru yang akan ditulis (posting) di Instagram @perpustakaandikbud. Berdasarkan indikator follower yang mengecek tulisan (posting) terbaru @perpustakaandikbud, sebagian besar responden menyatakan bahwa responden selalu mengecek hasil tulisan (posting) terbaru yang ditulis (posting) di akun Instagram @perpustakaandikbud. Sementara itu, indikator follower yang merasa senang pada hasil tulisan (posting) @perpustakaandikbud, hampir seluruh responden menyatakan bahwa mereka merasa senang ketika melihat atau membaca pesan publikasi yang ditulis (posting)Instagram @perpustakaandikbud.

Customer engagement dalam dimensi interaction mengacu pada setiap interaksi dan hubungan timbal-balik antara konsumen dengan institusi maupun antar konsumen itu sendiri. Dimensi interaction dapat dikatakan sebagai dimensi customer engagement yang paling mudah terlihat karena biasanya berupa aktivitas yang dapat menggunakan pengukuran, seperti jumlah like, komentar, dan share. Dimensi interaction dalam penelitian ini terdiri dari 4 indikator yang menggambarkan situasi ketika follower memberikan like dan komentar pada konten publikasi. Selain itu, dimensi ini juga membagikan serta merekomendasikan konten publikasi Instagram @perpustakaandikbud kepada orang lain.

Berdasarkan indikator follower yang memberi like pada tulisan (post) @perpustakaandikbud, hampir seluruh responden menyatakan bahwa mereka memberikan like (heart) pada pesan publikasi yang ditulis (post) oleh Instagram @perpustakaandikbud. Hal ini mendukung indikator sebelumnya yang menyatakan bahwa hampir seluruh 
responden menyukai pesan publikasi yang ditulis (post) Instagram @perpustakaandikbud. Lalu pada indikator follower yang memberi komentar pada pesan (posting) @perpustakaandikbud, sebagian kecil responden menyatakan bahwa responden memberikan komentar pada pesan publikasi yang ditulis (post) oleh Instagram @perpustakaandikbud. Hal ini menunjukkan bahwa sebagian besar responden yang menyukai konten publikasi Instagram @perpustakaandikbud hanya memberikan like saja dan tidak memberikan komentar. Sementara pada indikator follower yang membagikan tulisan (post) @perpustakaandikbud, sebagian besar responden menyatakan bahwa responden membagikan pesan publikasi yang ditulis (post) oleh Instagram @perpustakaandikbud. Hal ini didukung melalui indikator follower yang merekomendasikan Perpustakaan Kemendikbud, di mana hampir seluruh responden menyatakan bahwa mereka merekomendasikan konten tersebut kepada teman atau keluarga.

Adapun variabel minat kunjungan perpustakaan mengacu pada keinginan responden untuk mengunjungi dan memanfaatkan pelayanan Perpustakaan Kemendikbud. Variabel minat kunjungan dalam penelitian ini terdiri dari 11 indikator yang menggambarkan pengetahuan, perasaan, dan tindakan responden terhadap Perpustakaan Kemendikbud. Indikator pertama, mengenai lokasi Perpustakaan Kemendikbud. Hampir seluruh responden menyatakan bahwa lokasi perpustakaan tersebut strategis karena berada di pusat kota Jakarta dan dekat dengan beberapa institusi pendidikan berupa sekolah dan universitas. Perpustakaan Kemendikbud pun dapat dilalui berbagai kendaraan umum yang aksesnya mudah, seperti Transjakarta dan Moda Raya Terpadu (MRT).

$$
\text { Indikator kedua mengenai }
$$

pengetahuan follower tentang fasilitas yang dimiliki Perpustakaan Kemendikbud. Hampir seluruh responden menyatakan bahwa mereka mengetahui berbagai fasilitas yang ada di perpustakaan dan cara menggunakannya. Indikator ketiga mengenai pengetahuan follower tentang pelayanan Perpustakaan Kemendikbud. Sebagian besar responden menyatakan bahwa mereka mengetahui berbagai jenis pelayanan seperti yang dimiliki perpustakaan pada umumnya, yaitu layanan sirkulasi, referensi, audio-visual, user-education, layanan keanggotaan, dan layanan koleksi anak.

Indikator keempat mengenai pengetahuan follower tentang koleksi Perpustakaan Kemendikbud. Sebagian besar responden menyatakan bahwa mereka mengetahui berbagai jenis koleksi di perpustakaan tersebut. Menurut responden, koleksi di perpustakaan ini didominasi koleksi dengan subjek pendidikan dan kebudayaan karena perpustakaan berada di bawah naungan, contohnya koleksi terbitan lokal Kementerian Pendidikan dan Kebudayaan. Selain itu, terdapat pula yang koleksi bersifat umum, seperti sains, manajemen, ekonomi, dan koleksi fiksi yang memang diperuntukkan bagi masyarakat luas sebab perpustakaan ini memiliki pelayanan keanggotaan bagi umum.

Indikator kelima mengenai pengetahuan follower tentang acara (event) yang ada di Perpustakaan Kemendikbud. Sebagian besar responden menyatakan bahwa mereka mengetahui berbagai acara yang diselenggarakan di perpustakaan tersebut. Adapun indikator keenam mengenai kesukaan follower terhadap Perpustakaan 
Kemendikbud. Hampir seluruh responden menyatakan bahwa mereka menyukai perpustakaan tersebut. Selain itu, indikator ketujuh menunjukkan bahwa hampir seluruh responden memiliki keinginan untuk datang ke Perpustakaan Kemendikbud untuk memanfaatkan pelayanan dan koleksi yang ada. Indikator kedelapan menunjukkan bahwa sebagian besar responden berkunjung ke Perpustakaan Kemendikbud setidaknya satu kali dalam seminggu.

Berdasarkan indikator kesembilan dapat terlihat bahwa sebagian besar responden datang ke Perpustakaan Kemendikbud untuk mencari informasi dan referensi khususnya tentang pendidikan dan kebudayaan. Indikator kesepuluh menunjukkan bahwa sebagian responden datang ke Perpustakaan Kemendikbud karena ingin mengikuti acara yang diselenggarakan di perpustakaan tersebut. Terakhir, dalam indikator sebelas, terlihat bahwa sebagian besar responden merasa senang dan bangga ketika mengunjungi Perpustakaan Kemendikbud.

Peneliti setelah melakukan analisis deskriptif pada data responden dan data penelitian, kemudian mengategorikan data untuk melihat kecenderungan responden pada masing-masing variabel penelitian. Setelah itu, sesuai rumus Istiningrum and Esfandari (2019), peneliti mengklasifikasikan data ke dalam tiga kategori, yaitu tinggi, sedang, dan rendah. Hasil kategori data dapat dilihat sebagai berikut.

\section{Tabel 1}

Customer engagement $(\mathrm{X})$ Instagram @perpustakaandikbud

\begin{tabular}{llll}
\hline No. & Engagement & $\mathbf{f}$ & $\%$ \\
\hline 1 & Tinggi & 69 & 83,1 \\
2 & Sedang & 14 & 16,9 \\
3 & Rendah & 0 & 0,0 \\
& Jumlah & 83 & 100 \\
\hline
\end{tabular}

Sumber: Pengolahan data, 2019
Berdasarkan pada tabel 1 di atas, dapat diketahui bahwa dari 83 responden, sebanyak 69 responden dengan persentase $83,1 \%$ termasuk ke dalam kategori tinggi. Maka, dapat dikatakan bahwa hampir seluruh responden memiliki tingkat keterlibatan konsumen (customer engagement) yang tinggi dengan Instagram @perpustakaandikbud, di antaranya absorption, dedication, vigor dan interaction.

Selain itu, pada tabel 2 di atas, dapat dilihat bahwa dari dimensi absorption, dari 83 responden terdapat 74 responden dengan persentase $89,2 \%$ termasuk ke dalam kategori tinggi. Maka dapat dikatakan bahwa hampir seluruh responden memiliki tingkat penerimaan (absorption) yang tinggi dalam customer engagement Instagram @perpustakaandikbud. Dimensi absorption terdiri atas aspek ketertarikan dan perhatian responden terhadap konten publikasi Instagram @perpustakaandikbud.

Tabel 2

Dimensi absorption, dedication, vigor dan interaction $\left(\mathrm{X}_{1}, \mathrm{X}_{2}, \mathrm{X}_{3}\right.$ dan $\left.\mathrm{X}_{4}\right)$ Instagram @perpustakaandikbud

\begin{tabular}{llllll}
\hline $\begin{array}{l}\text { Customer } \\
\text { engagement }\end{array}$ & & Tinggi & Sedang & Rendah & Total \\
\hline \multirow{2}{*}{ Absorption } & f & 74 & 8 & 1 & 83 \\
& $\%$ & 89,2 & 9,6 & 1,2 & 100 \\
Dedication & f & 72 & 11 & 0 & 83 \\
& $\%$ & 86,7 & 13,3 & 0,0 & 100 \\
Vigor & f & 50 & 29 & 4 & 83 \\
\multirow{2}{*}{ interaction } & $\%$ & 60,2 & 34,9 & 4,8 & 100 \\
& f & 56 & 24 & 3 & 83 \\
& $\%$ & 67,5 & 28,9 & 3,6 & 100 \\
\hline
\end{tabular}

Sumber: Pengolahan data, 2019

Seperti yang telah dijelaskan sebelumnya, dimensi absorption mengacu pada ketertarikan dan perhatian responden institusi/lembaga (Hollebeek, Glynn, \& Brodie, 2014). Pada dimensi ini, digambarkan bahwa responden memiliki 
konsentrasi penuh ketika memainkan perannya sebagai konsumen. Mereka akan merasa waktu berlalu dengan cepat ketika melakukan interaksi dengan institusi/lembaga. Responden ketika melihat dan tertarik pada pesan publikasi yang ditulis (posting) oleh Instagram @perpustakaandikbud, maka responden akan melakukan konsentrasi menerima informasi yang tertera pada konten publikasi yang ditulis tersebut. Responden akan memperhatikan tampilan visual (infographic) dan membaca gambaran (caption) yang tertera pada konten publikasi tersebut.

Sesuai tabel 2 dapat diketahui bahwa dimensi dedication dari 83 responden terdapat 72 responden dengan persentase $86,7 \%$ termasuk ke dalam kategori tinggi. Maka dapat dikatakan bahwa hampir seluruh responden memiliki tingkat dedikasi (dedication) yang tinggi dalam customer engagement Instagram @perpustakaandikbud. Dimensi dedication terdiri atas aspek rasa kepemilikan di mana responden merasa senang dan bangga terhadap konten publikasi Instagram @perpustakaandikbud yang membuat responden seringkali terinspirasi.

Menurut Hollebeek et al., (2014), dedication mengacu kepada rasa kepemilikan konsumen yang merefleksikan aspek emosional, di mana responden merasa bangga dan antusias ketika memainkan peran sebagai konsumen. Responden seringkali merasa terinspirasi oleh interaksi yang dilakukan institusi/lembaga. Pengalaman personal dapat diperoleh melalui interaksi dengan institusi/lembaga yang menumbuhkan pengalaman emosional. Dimana semakin tinggi aspek emosional yang muncul dalam pengalaman konsumen, maka akan menumbuhkan rasa empati, percaya, dan rasa kepemilikan oleh konsumen.

Pada tabel 2, terlihat bahwa dimensi vigor dari 83 responden. Responden sejumlah 50 orang dengan persentase $60,2 \%$ termasuk ke dalam kategori tinggi. Maka, dapat dikatakan bahwa sebagian besar responden memiliki tingkat semangat (vigor) yang tinggi dalam customer engagement Instagram @perpustakaandikbud. Dimensi vigor mengacu pada level energi dan kegembiraan responden. Di mana responden berkeinginan untuk memberikan usaha dan waktu yang lebih terhadap konten publikasi Instagram @perpustakaandikbud yang menyebabkan responden seringkali mengecek hasil tulisan (posting) terbaru di Instagram @perpustakaandikbud.

Dimensi vigor mengacu kepada level energi dan kegembiraan pengguna ketika berinteraksi dengan institusi/lembaga maupun dengan pengguna lain. Vigor juga mengarah kepada keinginan pengguna untuk menginvestasikan waktu dan usaha pada perannya sebagai pengguna dari organisasi/lembaga. Pengguna akan cenderung memiliki loyalitas pada institusi/lembaga. Responden dalam hal ini memiliki kecenderungan untuk mengecek tulisan (posting) terbaru dari Instagram @perpustakaandikbud. Maka ini berarti, responden akan melakukan kunjungan berulang pada akun Instagram @perpustakaandikbud untuk melihat apakah ada konten publikasi baru atau tidak. Responden pun merasa senang ketika melihat dan membaca konten publikasi yang ditulis (posting) oleh Instagram @perpustakaandikbud.

Berdasarkan tabel 2 dapat terlihat pula bahwa dalam dimensi interaction, responden dari 83 orang, sebanyak 56 
orang memiliki persentase $67,5 \%$ termasuk ke dalam kategori tinggi. Maka dapat dikatakan bahwa sebagian besar responden memiliki tingkat interaksi (interaction) yang tinggi dalam customer engagement

Instagram

@perpustakaandikbud. Dimensi interaction mengarah kepada berbagai interaksi dan hubungan timbal-balik baik antara responden dengan Instagram @perpustakaandikbud maupun antar konsumen. Interaksi ini biasanya berupa pemberian tanda like, menulis komentar, saling berbagi, dan memberikan rekomendasi konten (sharing).

Dimensi interaction mengarah pada berbagai interaksi dan hubungan timbalbalik antara pengguna dengan organisasi, maupun antar customer (Hollebeek et al., 2014). Responden dalam hal ini, berinteraksi dalam Instagram @perpustakaandikbud dengan cara memberikan tanda like dan komentar sebagai bentuk rasa suka pada konten publikasi yang ditulis (posting) dan membagikannya, melalui direct message kepada orang lain atau mengirimkan pada Instagram story.

Berdasarkan pada tabel 3, dapat diketahui bahwa dari 83 responden, sebanyak 61 orang dengan persentase $73,5 \%$ termasuk ke dalam kategori tinggi. Maka dapat dikatakan bahwa hampir seluruh responden memiliki minat kunjungan perpustakaan yang tinggi.

\section{Tabel 3}

Minat kunjungan perpustakaan (Y) ke

Perpusdikbud

\begin{tabular}{llll}
\hline No. & $\begin{array}{l}\text { Minat kunjungan } \\
\text { perpustakaan }\end{array}$ & $\mathbf{f}$ & $\mathbf{\%}$ \\
\hline 1 & Tinggi & 61 & 73,5 \\
2 & Sedang & 21 & 25,2 \\
3 & Rendah & 1 & 1,2 \\
& Jumlah & 83 & 100 \\
\hline
\end{tabular}

Sumber: Pengolahan data, 2019
Minat kunjungan perpustakaan mengarah pada ketertarikan responden kepada Perpustakaan Kemendikbud dan keinginan responden untuk datang mengunjungi Perpustakaan. Selain itu, responden berkunjung ke Perpustakaan Kemendikbud untuk melakukan berbagai aktivitas, menggunakan fasilitas, memanfaatkan layanan dan koleksi, mencari referensi, dan menghadiri acara yang diselenggarakan Perpustakaan Kemendikbud.

Minat kunjungan perpustakaan dapat diartikan sebagai keinginan individu untuk mengunjungi perpustakaan dan memanfaatkan pelayanan serta koleksi yang ada. Minat sesuai aspek kognitif didasari atas apa yang diketahui dan pernah dipelajari sedangkan aspek afektif berdasarkan perasaan dan emosi terhadap objek. Minat kunjungan perpustakaan memiliki satu aspek tambahan, yaitu aspek konatif yang ditunjukkan dengan tindakan berkunjung ke perpustakaan. Dalam hal ini, ketika responden sudah mengetahui informasi mengenai Perpustakaan Kemendikbud melalui konten publikasi yang ditulis (posting) di Instagram @perpustakaandikbud dan responden menyukainya maka responden akan memiliki kecenderungan mengunjungi Perpustakaan Kemendikbud ketika ada waktu luang. Responden berkeinginan untuk menggunakan dan memanfaatkan layanan serta koleksi yang ada atau mengunjungi acara yang diselenggarakan di Perpustakaan Kemendikbud.

Untuk mengetahui hubungan antara customer engagement (absorption, dedication, vigor, interaction) dengan minat kunjungan perpustakaan, peneliti melakukan penghitungan menggunakan korelasi rank 
spearman. Hasil analisis dapat dilihat pada tabel 4 .

Tabel 4

Hubungan customer engagement dengan minat kunjungan perpustakaan

\begin{tabular}{|c|c|c|c|c|}
\hline Variabel & Rs & $\mathbf{t}_{\text {hitung }}$ & $t_{\text {tabel }}$ & Kesimpulan \\
\hline$X-Y$ & 0,521 & 4,417 & 1,663 & $\begin{array}{l}\text { Ada } \\
\text { hubungan }\end{array}$ \\
\hline$X 1-Y$ & 0,484 & 4,121 & 1,663 & $\begin{array}{l}\text { Ada } \\
\text { hubungan }\end{array}$ \\
\hline$X 2-Y$ & 0,401 & 3,448 & 1,663 & $\begin{array}{l}\text { Ada } \\
\text { hubungan }\end{array}$ \\
\hline$X 3-Y$ & 0,682 & 5,675 & 1,663 & $\begin{array}{l}\text { Ada } \\
\text { hubungan }\end{array}$ \\
\hline$X 4-Y$ & 0,592 & 4,977 & 1,663 & $\begin{array}{l}\text { Ada } \\
\text { hubungan }\end{array}$ \\
\hline
\end{tabular}

Sumber: Pengolahan data, 2019

Berdasarkan tabel 4, dapat diketahui bahwa, pertama koefisien korelasi antara customer engagement $(X)$ dengan minat kunjungan perpustakaan $(\mathrm{Y})$ sebesar 0,521. Ini berarti bahwa antara customer engagement dengan minat kunjungan perpustakaan memiliki keeratan hubungan yang rendah. Uji signifikansi dihitung menggunakan rumus ini.

$$
t_{\text {hitung }}=\frac{r \sqrt{n-2}}{\sqrt{1-r^{2}}}=\frac{0,52 \sqrt{83-2}}{\sqrt{1-(0,52)^{2}}}
$$

Sesuai rumus di atas, angka yang dihasilkan 4,417. Sementara $t_{\text {tabel }}$ didapatkan dari $\mathrm{a}=0,05, \mathrm{n}=83$ dan nilai $\mathrm{dk}=\mathrm{n}-2=81$, sehingga diperoleh $\mathrm{t}_{\text {tabel }}$ senilai 1,663. Rumus $t_{\text {hitung }}(4,417)>t_{\text {tabel }}$ $(1,663)$, maka $\mathrm{H}_{\mathrm{i}}$ diterima sehingga dapat dikatakan bahwa terdapat hubungan antara customer engagement dengan minat kunjungan perpustakaan.

Hal ini sesuai teori customer engagement yang dikemukakan Brodie et al., (2011) bahwa adanya serangkaian aktivitas customer engagement dapat memengaruhi keadaan psikologis konsumen dan dapat menghasilkan sebuah persepsi tertentu. Konsumen yang telah melakukan berbagai kegiatan engagement dengan Instagram @perpustakaandikbud akan memiliki sejumlah pengalaman interaktif. Akumulasi dari pengalaman ini akan memengaruhi kondisi psikologis konsumen dalam bentuk dorongan kunjungan ke Perpustakaan Kemendikbud dan memanfaatkan koleksi serta layanan yang ada. Maka semakin tinggi engagement follower dengan Instagram @perpustakaandikbud maka semakin banyak pengalaman interaktif yang dirasakan follower dan semakin tinggi pula minat kunjungan perpustakaan follower terhadap Perpustakaan Kemendikbud.

Kedua, koefisien korelasi antara absorption $\left(\mathrm{X}_{1}\right)$ dengan minat kunjungan perpustakaan (Y) sebesar 0,484. Ini berarti bahwa antara customer engagement dengan minat kunjungan perpustakaan memiliki tingkat keeratan hubungan yang rendah. Uji signifikansi dihitung menggunakan rumus yang sama sehingga menghasilkan angka 4,121. Sementara tabel didapatkan dari $\mathrm{a}=0,05, \mathrm{n}=83$ dan nilai $\mathrm{dk}=\mathrm{n}-2=$ 81 sehingga diperoleh $t_{\text {tabel }}$ senilai 1,663 . Rumus thitung $(4,121)>t_{\text {tabel }}(1,663)$, maka $\mathrm{H}_{\mathrm{i}}$ diterima. Hal ini dapat dikatakan bahwa terdapat hubungan antara dimensi absorption dengan minat kunjungan perpustakaan.

Brodie et al. (2011) mendeskripsikan absorption sebagai keadaan ketika konsumen merasa tertarik saat melihat atau menerima suatu pelayanan maka konsumen akan mulai memperhatikan berbagai informasi terkait pelayanan tersebut. Hal ini mendorong konsumen untuk mulai mencari tahu informasi mengenai pelayanan tersebut. Berbagai informasi yang didapatkan akan 
menambah pengetahuan konsumen dan dapat mendorong konsumen untuk mau menggunakan pelayanan. Konsumen dapat menemukan informasi mengenai pelayanan, koleksi, dan kegiatan dengan melakukan engagement pada pesan (posting) dan story Instagram @perpustakaandikbud. Maka semakin tinggi penerimaan (absorption) follower dengan Instagram @perpustakaandikbud maka semakin tinggi pula minat kunjungan follower terhadap perpustakaan.

Ketiga, koefisien korelasi antara dedication $\left(\mathrm{X}_{2}\right)$ dengan minat kunjungan perpustakaan $(\mathrm{Y})$ sebesar 0,401. Ini berarti bahwa antara customer engagement dengan minat kunjungan perpustakaan memiliki keeratan hubungan yang rendah. Uji signifikansi dihitung menggunakan rumus yang sama, sehingga menghasilkan angka 3,448 . Sementara $t_{\text {tabel }}$ didapat dari $a=0,05$, $\mathrm{n}=83$ dan nilai $\mathrm{dk}=\mathrm{n}-2=81$ sehingga diperoleh $t_{\text {tabel }}$ senilai 1,663 . Rumus $t_{\text {hitung }}$ $(3,448)>t_{\text {tabel }}(1,663)$ maka $H_{i}$ diterima. Maka dapat dikatakan bahwa terdapat hubungan antara dimensi dedication dengan minat kunjungan perpustakaan.

Brodie et al. (2011) menjelaskan dedication sebagai rasa kepemilikan konsumen yang disebabkan rasa senang yang dirasakan konsumen. Ketika konsumen merasa senang saat melakukan engagement melalui Instagram @ perpustakaandikbud, maka timbul suatu rasa ingin memiliki atau dalam hal ini, merasakan pelayanan yang disediakan Perpustakaan Kemendikbud. Hal ini berarti semakin tinggi dedikasi (dedication) follower melalui Instagram @perpustakaandikbud maka semakin tinggi pula minat kunjungan perpustakaan follower terhadap Perpustakaan Kemendikbud.
Keempat, koefisien korelasi antara vigor $\left(X_{3}\right)$ dengan minat kunjungan perpustakaan $(\mathrm{Y})$ sebesar 0,682 . Ini berarti bahwa antara customer engagement dengan minat kunjungan perpustakaan memiliki keeratan hubungan yang rendah. Uji signifikansi dihitung menggunakan rumus yang sama sehingga menghasilkan angka 5,675 . Sementara $t_{\text {tabel }}$ didapat dari $a=0,05$, $\mathrm{n}=83$ dan nilai $\mathrm{dk}=\mathrm{n}-2=81$ sehingga diperoleh $t_{\text {tabel }}$ senilai 1,663 . Rumus $t_{\text {hitung }}$ $(5,675)>t_{\text {tabel }}(1,663)$ maka $_{\mathrm{i}}$ diterima. Hal ini dapat dikatakan bahwa terdapat hubungan antara dimensi vigor dengan minat kunjungan perpustakaan.

Vigor berdasarkan Brodie et al., (2011) merupakan tingkat energi dan kegembiraan konsumen. Ketika konsumen merasakan kegembiraan ketika melakukan engagement melalui Instagram @perpustakaandikbud maka konsumen akan menyalurkan energinya dengan memberikan usaha dan waktu untuk berkunjung dan menggunakan pelayanan di Perpustakaan Kemendikbud. Maka berarti semakin tinggi semangat (vigor) follower melalui Instagram @perpustakaandikbud maka semakin tinggi pula minat kunjungan perpustakaan follower terhadap Perpustakaan Kemendikbud.

Kelima, koefisien korelasi antara interaction $\left(\mathrm{X}_{4}\right)$ dengan minat kunjungan perpustakaan $(\mathrm{Y})$ sebesar 0,592. Ini berarti bahwa antara customer engagement dengan minat kunjungan perpustakaan memiliki keeratan hubungan yang rendah. Uji signifikansi dihitung menggunakan rumus yang sama, sehingga menghasilkan angka 4,977. Sementara $t_{\text {tabel }}$ didapat dari $a=0,05$, $\mathrm{n}=83$ dan nilai $\mathrm{dk}=\mathrm{n}-2=81$ sehingga diperoleh $t_{\text {tabel }}$ senilai 1,663 . Rumus $t_{\text {hitung }}$ $(4,977)>t_{\text {tabel }}(1,663)$ maka $H_{i}$ diterima. Hal ini dapat dikatakan bahwa terdapat 
hubungan antara dimensi interaction dengan minat kunjungan perpustakaan.

Interaction menurut Brodie et al., (2011) merupakan pelbagai interaksi yang dilakukan antara konsumen dengan penyedia pelayanan atau interaksi antar konsumen. Ketika konsumen memiliki intensitas interaksi tinggi dengan penyedia pelayanan dan konsumen lain maka akan memengaruhi psikologis konsumen yang mengarah pada pembentukan persepi konsumen terhadap layanan. Semakin tinggi interaksi (interaction) follower dengan Instagram @perpustakaandikbud maka semakin tinggi pula minat kunjungan perpustakaan follower terhadap Perpustakaan Kemendikbud.

\section{SIMPULAN}

Berdasarkan hasil dan pembahasan di atas, maka dapat ditarik beberapa kesimpulan. Pertama dimensi absorption dari customer engagement instagram @perpustakaandikbud memiliki hubungan dengan minat kunjungan perpustakaan di kalangan follower aktif. Hal ini berarti, follower yang memiliki tingkat penerimaan (absorption) tinggi memiliki kecenderungan untuk mengunjungi Perpustakaan Kemendikbud. Kedua, dimensi dedication dari customer engagement Instagram @perpustakaandikbud memiliki hubungan dengan minat kunjungan perpustakaan di kalangan follower aktif. Follower yang memiliki tingkat dedikasi (dedication) tinggi memiliki kecenderungan untuk mengunjungi

Perpustakaan

Kemendikbud. Ketiga, dimensi vigor dari customer engagement

Instagram @perpustakaandikbud memiliki hubungan dengan minat kunjungan perpustakaan di kalangan follower aktif. Follower yang memiliki tingkat semangat (vigor) tinggi memiliki kecenderungan untuk mengunjungi Perpustakaan Kemendikbud. Keempat, dimensi interaction dari customer engagement Instagram @perpustakaandikbud memiliki hubungan dengan minat kunjungan perpustakaan di kalangan follower aktif. Follower yang memiliki tingkat interaksi (interaction) tinggi memiliki kecenderungan untuk mengunjungi Perpustakaan Kemendikbud. Dengan demikian, terdapat hubungan antara customer engagement follower Instagram @perpustakaandikbud dengan minat kunjungan. Oleh karena itu, Perpustakaan Kemendikbud lebih meningkatkan pengelolaan konten Instagram @perpustakaandikbud agar followers tetap semangat untuk melakukan engagement dan semangat mengunjungi Perpustakaan Kemendikbud. Untuk membuat followers semakin terdorong melakukan engagement maka sebaiknya dibuat konten publikasi yang lebih interaktif. Followers tidak hanya memberikan like, komentar, membagikan konten, dan berdiskusi dengan sesama followers. Selanjutnya untuk meningkatkan pengalaman interaktif dan kreatif bersama (co-creative) followers, maka Perpustakaan Kemendikbud sebaiknya menyelenggarakan story-live yang dikemas dalam penyelenggaraan acara. Pengalaman interaktif followers diharapkan dapat meningkatkan engagement dan loyalitas pada Perpustakaan Kemendikbud. Sebaiknya frekuensi penyelenggaraan acara lebih ditingkatkan agar tingkat kunjungan ke perpustakaan juga semakin meningkat. Penelitian mengenai customer engagement pada media sosial Instagram @perpustakaandikbud ini masih dapat dikembangkan lagi untuk mencari tahu apakah customer engagement juga dapat memengaruhi tingkat loyalitas konsumen terhadap Perpustakaan Kemendikbud. 


\section{DAFTAR PUSTAKA}

Arceneaux, P. C., \& Dinu, L. F. (2018). The social mediated age of information: Twitter and Instagram as tools for information dissemination in higher education. New Media $\mathcal{E}$ Society, 20(11), 1-22.

https:/ / doi.org/10.1177/14614448187 68259

Brodie, R. J., Hollebeek, L. D., Juric', B., \& Ilic', A. (2011). Customer engagement: Conceptual domain, fundamental propositions and implications for research. Journal of Service Research, 14(3), 252-271.

https:/ / doi.org/10.1177/10946705114 11703

Brodie, R. J., Ilic', A., Juric', B., \& Hollebeek, L. D. (2013). Consumer engagement in a virtual brand community: An exploratory analysis. Journal of Business Research, 66(1), 105114.

https:// doi.org/10.1016/j.jbusres.201 1.07.029

Gibbs, M., Meese, J., Arnold, M., Nansen, B., \& Carter, M. (2014). \#Funeral and Instagram: death, social media, and platform vernacular. Information, Communication \& Society, 18(3), 255-268. https:/ / doi.org/10.1080/1369118X.20 14.987152

Hirschmann, R. (2018). Share of beauty influencers Indonesia 2018, by social media platform. Statista.com. Retrieved from

https://www.statista.com/statistics/ 1066339/indonesia-share-of-beautyinfluencers-by-channel/

Hollebeek, L. D., Glynn, M. S., \& Brodie, R. J. (2014). Consumer brand engagement in social media: Conceptualization, scale development and validation. Journal of Interactive
Marketing, 28(2), 149-165.

https:/ /doi.org/10.1016/j.intmar.201

3.12.002

Istiningrum, \& Esfandari, D. A. (2019). Pengaruh mobile Apps MyIndihome terhadap customer engagement di Kota Bandung. Jurnal Bisnis Dan Manajemen, 6(1), 1-5. https://doi.org/10.26905/jbm.v6i1.30 29

Kaplan, A., \& Haenlein, M. (2017). Users of the world, unite! The challenges and opportunities of social media. Business Horizon, 53(1), 59-68.

https:/ / doi.org/10.1016/j.bushor.200 9.09.003

Mahayani, O. C., Aknuranda, I., \& Kusyanti, A. (2019). Pengaruh customer engagement melalui media sosial terhadap kepercayaan merek: Studi kasus Instagram Shopee. Jurnal Pengembangan Teknologi Informasi Dan Ilmu Komputer, 3(4), 3301-3310. http://j-ptiik.ub.ac.id/index.php/jptiik/article/view/4920/2313

Rahmawati, E., \& S. (2015). Pengaruh customer engagement terhadap kepuasan pelanggan dan kepercayaan merek serta dampaknya pada loyalitas merek. JREM: Jurnal Riset Ekonomi Dan Manajemen, 15(2), 246261.

https:/ / doi.org/10.17970/jrem.15.150 204.ID

Riyanto, A. D. (2019). Hootsuite (we are social): Indonesian digital report 2019. Andi.Link. Retrieved from https://andi.link/hootsuite-we-aresocial-indonesian-digital-report-2019/

Safira, F. \& Irawati, I. (2020). Hubungan literasi media sosial pustakawan perguruan tinggi dengan kualitas pemanfaatan e-resources perpustakaan. Lentera Pustaka: Jurnal 
Kajian Ilmu Perpustakaan, Informasi

Dan Kearsipan, 6(1), 1-12. https://doi.org/10.14710/lenpust.v6i 1.25325

Sherlyanita, A. K., \& Rakhmawati, N. A. (2016). Pengaruh dan pola aktivitas penggunaan internet serta media sosial pada siswa SMPN 52 Surabaya. Journal of Information Systems Engineering and Business Intelligence, 2(1), 17-22.

https://doi.org/10.20473/jisebi.2.1.17 $-22$

Statista Research Department. (2018). Information sources for female consumers on 11.11 shopping event Indonesia 2018. Statista.com. Retrieved from https:/ / www.statista.com/statistics/ 993494/indonesia-female-consumersexpenditure-1111-shopping-event/

Sukamdewi, R. A., \& Prihatsanti, U. (2017). Hubungan antara brand trust dengan customer engagement pada mahasiswi pengguna Wardah kosmetik. Jurnal Empati, 6(4), 131-136. Retrieved from https://ejournal3.undip.ac.id/index. php/empati/article/view/20001/188 85

Syafi'i, A., Marfiyanto, T., \& Rodiyah, S. K. (2018). Studi tentang prestasi belajar siswa dalam berbagai aspek dan faktor yang mempengaruhi. Jurnal Komunikasi Pendidikan, 2(2), 115-123. https://doi.org/10.32585/jkp.v2i2.11 4

Vivek, S. D., Beatty, S. E., \& Morgan, R. M. (2012). Customer engagement: Exploring customer relationships beyond purchase. Journal of Marketing Theory and Practice, 20(2), 127-145. https://doi.org/10.2753/MTP10696679200201 
